\title{
Proportion of women on the editorial committees of dental journals in the world
}

Proporção de mulheres nos comitês editoriais de revistas odontológicas no mundo

Christian Renzo AQUINO-CANCHARI ${ }^{1}$ (), Roberto OJEDA-GÓMEZ ${ }^{2}$ (), Nadia Inés MERIZALDE-ORTEGA ${ }^{3}$ (1), Ana Katthia RODRÍGUEZ-VALLADARES ${ }^{4}$ (1)

1 - Universidad Peruana Los Andes, Facultad de Medicina Humana, Sociedad Científica de Estudiantes de Medicina Los Andes. Huancayo, Perú.

2 - Universidad Señor de Sipán, Facultad de Estomatología. Chiclayo, Perú.

3 - Práctica privada. Lima, Perú.

4 - Universidad Peruana Cayetano Heredia, Facultad de Estomatologia. Lima, Perú.

\begin{abstract}
Objective: Despite the increase in the female contribution to careers in the health sector, Dentistry has shown slow progress towards gender equality. The objective of this study was to quantify the proportion of women in the editorial committees of dental journals in the world. Material and Methods: Dental journals published in the world were compiled, which met inclusion criteria: dental journals indexed to Scopus in their 2020 edition, access to the composition of the editorial committee. Non-current journals, without access to their website, journals not classified in a quartile, and journals with publishers outside their country of origin, were excluded. The selection of journals was carried out from January 11 to 19, 2021. The analysis variables were the composition of the editorial committee, dental specialty according to the SJR category and the title of the journal, quartile of the journal, and country of origin of the editorial headquarters. Results: One hundred eighty nine journals were identified. Women represented $22.91 \%$ for the position of director or editor-in-chief. With respect to associate editors and members of the editorial board, $24.76 \%$ and $22.91 \%$ were women, respectively. Likewise, greater female participation was observed in Q2 and Q1 journals and in thematic areas of Geriatric Dentistry, Dental Education, Dental Public Health, and Basic Sciences. Conclusion: The findings demonstrate the low proportion of women on the editorial boards of dental journals in the world.
\end{abstract}

\section{KEYWORDS}

Gender; Women; Dentistry; Editor; Editorial board; Research.

\section{RESUMO}

Objetivo: Apesar do aumento da contribuição feminina para as carreiras no setor da saúde, a odontologia tem apresentado avanços lentos em direção à equidade de gênero. O objetivo deste estudo foi quantificar a proporção de mulheres nos comitês editoriais de periódicos odontológicos no mundo. Material e Métodos: Foram compilados periódicos odontológicos publicados no mundo, que atenderam aos critérios de inclusão: periódicos odontológicos indexados ao Scopus em sua edição de 2020, acesso à composição do comitê editorial. Foram excluídos os periódicos não atuais, sem acesso ao site, os periódicos não classificados em quartil e os periódicos com editoras fora do país de origem. A seleção dos periódicos foi realizada no período de 11 a 19 de janeiro de 2021. As variáveis de análise foram a composição do comitê editorial, especialidade odontológica de acordo com a categoria SJR e o título do periódico, quartil do periódico e país de origem da sede do editorial. Resultados: Cento e oitenta e nove periódicos foram identificados. As mulheres representaram 22,91\% para o cargo de diretora ou redatora-chefe. Em relação aos editores associados e membros do comitê editorial, 24,76\% e 22,91\% eram mulheres, respectivamente. Da mesma forma, foi observada maior participação feminina nos periódicos 
Q2 e Q1 e nas áreas temáticas de Odontologia Geriátrica, Educação Odontológica, Saúde Pública Odontológica e Ciências Básicas. Conclusão: Os achados demonstram a baixa proporção de mulheres nos conselhos editoriais de periódicos odontológicos no mundo.

\section{PALAVRAS-CHAVE}

Gênero; Mulheres; Odontologia; Editor; Comitê Editorial; Pesquisar.

\section{INTRODUCTION}

According to the Global Gender Gap Index, it describes a current difference of $31.4 \%$ worldwide and that it will close in the next 108 years in the 115 countries evaluated [1]. Gender inequalities and inequities have existed throughout time, whether for historical, political, economic, social, cultural and religious reasons. The participation of women in the scientific field has decreased compared to the participation of men in scientific research [2].

The gender perspective gained interest when the low participation of women in scientific production was recognized as a problem [3]. Although the participation of women in various medical areas has increased, they remain a minority such as in dentistry.

Various phenomena such as the "glass ceiling", the "Curie effect" or the "Matilda effect", have been referenced as possible responses to the situation of women within the world scientific community and to demonstrate that, despite the increase in women in higher education or even becoming older compared to men, significant differences are still perceived in the promotion and permanence in specialization and postgraduate careers [4].

Research in dentistry has made progress in recent years worldwide, within which scientific journals help to disseminate it [5]. The editorial committee of a peer-reviewed scientific journal has a team of professionals responsible for producing the publication with the rigor and academic and scientific standards required for this type of publication [6]. There are efforts for a greater inclusion of women within editorial teams, but it is still insufficient. There are similar studies in medical journals $[7,8]$. However, there are no studies in dental journals worldwide. Therefore, the objective of the present study was to determine the proportion of women in the editorial committees of dental journals in the world.

\section{MATERIALS AND METHODS}

An observational, descriptive, cross-sectional study was carried out. Dental journals indexed to Scopus were included in their 2020 edition. A search was carried out on the Scimago Journal \& Country Rank (SJR) platform (https://www. scimagojr.com), of all the journal titles in the area «Dentistry», in «all subject categories», in «all regions / countries», and type «journals».

Two hundred eight journals were collected, which were subsequently screened by three of the authors, independently where dental journals indexed to Scopus were included in their 2020 edition; access to the composition of the editorial committee with the functions of editors-in-chief directors or, associate editors and editorial or advisory board. Non-current journals, without access to their website, journals not classified in a quartile, and journals with publishers outside their country of origin were excluded, leaving a total of 189 dental journals.

Gender of each publisher was classified according to the first names; in case of doubts Google search engine was entered to identify the gender according to profile images, accessing government web pages, those destined to project financing and / or work centers, as well as professional (LinkedIn, ResearchGate, Academia. edu) and general (Facebook, Twitter, Instagram) social networks, excluding companies and those not identified.

Variables according to the characteristics of the journals were the composition of the editorial committee: a) editors-in-chief or directors, b) associate editors (as) including co-editors, vice editors, section editors, technical editors, academic editors, associate editors and area editors, and c) editorial or advisory team that includes reviewers, committee and editorial board, we did not include editorial positions related to management in the analysis nor editorial or management and / or software functions. Likewise, the dental specialty was 
evaluated according to the $S J R$ category and the title of the journal, quartile of the journal classified from Q1 to Q4 and country of origin of the editorial headquarters.

The search for information was covered from January 11 to 19,2021

\section{Data analysis}

A registration form was prepared in the Microsoft Excel version 2017 program for data collection, including the variables studied. Statistical quantification was performed using the Statistical Package for Social Sciences (SPSS) statistical software, version 22 . The descriptive analysis was quantified through frequencies and percentages, and the Kruskal-Wallis test was used to determine the association, with a significance level $(p \leq 0.05)$.

\section{Ethical considerations}

The study did not require the approval of an ethics committee since the data are publicly available and freely accessible (https://www. scimagojr.com).

\section{RESULTS}

From a total of 208 journals, 19 journals were excluded, leaving a total of 189 scientific journals. According to the functions in the editorial committee, 207 directors/editors-inchief, 2,629 associate editors, and 6,774 members of the editorial board were included.

Regarding the positions in the editorial committees, for the position of director or editorin-chief, female participation was $22.91 \%$, with respect to the position of associate editors $24.76 \%$ were women, and for the members of the editorial board the $22.91 \%$ were women (Figure 1).

Regarding the quartile of the journal, there was evidence of a higher proportion of women in editorial positions in journals classified in Q2 (25.38\%), followed by Q1 (23.93\%), Q4 (19.18\%) and in Q3 (18.17\%) (Figure 2).

There was a greater proportion of women in the position of editor-in-chief or director in magazines from the countries of Chile (100\%), United Arab Emirates (100\%), Brazil (37.50\%), France $(33.33 \%)$, Denmark (33.33\%). In relation to the associate editor position, there was a greater representation of women in journals from the countries of China (66. 67\%), Cuba (57.14\%), Iran (52.18\%), Poland (42.86\%), Brazil (40.21\%). Regarding the members of the editorial team, there were more women in journals from the countries of Bulgaria (56.21\%), Poland (42.86\%), Cuba (44.44\%), Croatia (43.04\%), Sweden (33.33\%) (Table I).

In relation to the specialty, a higher proportion of women was observed in implantology journals (90.72 / 9.28), endodontics (89.96 / 10.04), periodontics (89.29/10.71), oral surgery (82.64 / 17.36) (Figure 3).

It was observed that when women held the position of editor-in-chief or director of the journal, it was associated with the participation of associate or associate editors $(\mathrm{p}=0.000)$ and as members of the editorial or advisory board $(\mathrm{p}=0.000)$. Likewise, no differences were found if the journal was specialized or general with female participation (Table II).

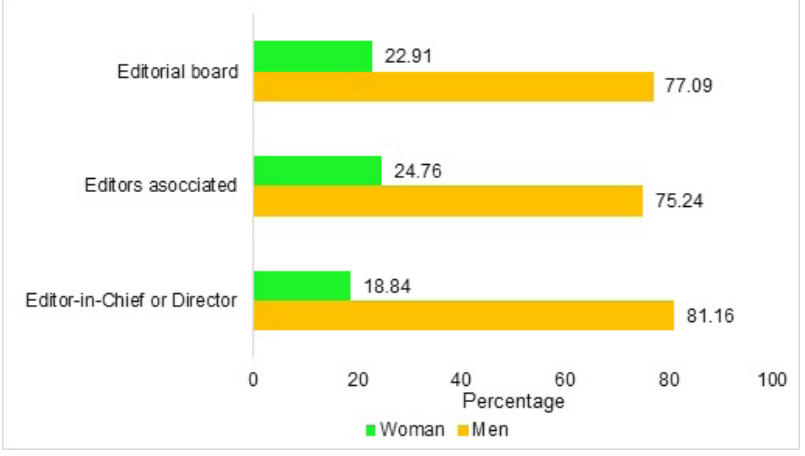

Figure 1 - Proportion of women according to editorial position in world dental journals.

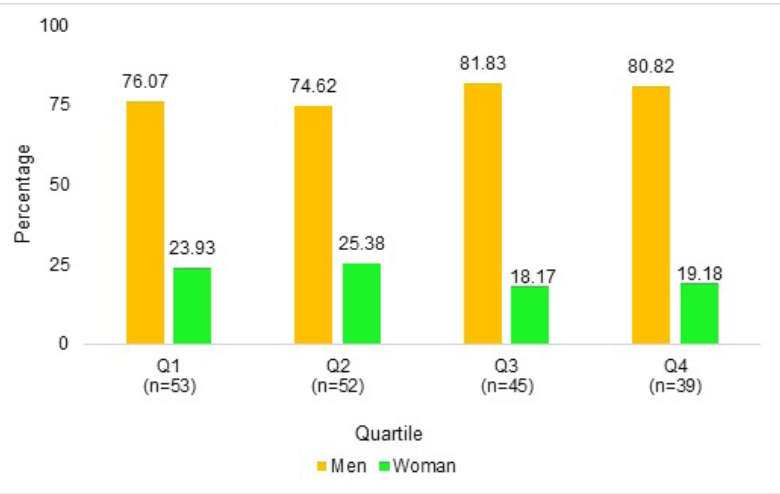

Figure 2 - Proportion of women in editorial committees of dental journlas in the world, according to quartile. $n=$ number of editors per journal quartile. 
Table I - Proportion of women to editorial position on committees of dental journals, by country.

\begin{tabular}{|c|c|c|c|c|c|c|}
\hline \multirow{2}{*}{ Country } & \multicolumn{2}{|c|}{ Editor in Chief or Director } & \multicolumn{2}{|c|}{ Editor associated } & \multicolumn{2}{|c|}{ Editorial board } \\
\hline & Men \% & Women \% & Men $\%$ & Women \% & Men \% & Women \% \\
\hline Australia & 100 & 0 & 66.66 & 33.33 & 100 & 0 \\
\hline Brazil & 62.50 & 37.50 & 59.79 & 40.21 & 71.31 & 28.69 \\
\hline Bulgaria & 100 & 0 & 50 & 50 & 43.59 & 56.41 \\
\hline Canada & 25 & 75 & 73.52 & 26.48 & 73.48 & 26.52 \\
\hline Chile & 0 & 100 & 37,5 & 62,5 & 100 & 0 \\
\hline China & 100 & 0 & 33.33 & 66.67 & 79.67 & 20.33 \\
\hline Croatia & 100 & 0 & 0 & 0 & 65.96 & 43.04 \\
\hline Cuba & 50 & 50 & 42.85 & 57.14 & 55.55 & 44.44 \\
\hline Denmark & 66,66 & 33,33 & 80 & 20 & 76.83 & 23.17 \\
\hline Egypt & 0 & 0 & 77.45 & 22.55 & 0 & 0 \\
\hline France & 66.67 & 33.33 & 67.56 & 32.44 & 100 & 0 \\
\hline Germany & 87,5 & 12,5 & 68.18 & 31.82 & 82 & 18 \\
\hline India & 94.44 & 5.55 & 85.76 & 14.24 & 78.47 & 21.53 \\
\hline Iran & 71.43 & 28.57 & 47.82 & 52.18 & 80.56 & 19.44 \\
\hline Italy & 100 & 0 & 80 & 20 & 79.73 & 20.27 \\
\hline Japan & 83.33 & 16.67 & 85.71 & 14.29 & 85.82 & 14.18 \\
\hline Malaysia & 0 & 100 & 50 & 50 & 50 & 50 \\
\hline Netherlands & 76.92 & 23.08 & 83.65 & 16.35 & 81.03 & 18.97 \\
\hline New Zealand & 100 & 0 & 0 & 100 & 70 & 30 \\
\hline Poland & 100 & 0 & 57.14 & 42.86 & 51.85 & 48.15 \\
\hline Russian Federation & 100 & 0 & 50 & 50 & 55.26 & 44.73 \\
\hline Saudi Arabia & 100 & 0 & 50 & 50 & 90.48 & 9.52 \\
\hline Serbia & 100 & 0 & 0 & 100 & 75.86 & 24.14 \\
\hline South Korea & 100 & 0 & 74.41 & 25.59 & 78.32 & 21.68 \\
\hline Spain & 100 & 0 & 68.88 & 31.12 & 69.98 & 30.02 \\
\hline Sweden & 100 & 0 & 100 & 0 & 66.67 & 33.33 \\
\hline Switzerland & 80 & 20 & 61.53 & 38.47 & 79.80 & 20.20 \\
\hline Taiwan & 100 & 0 & 90.32 & 9.68 & 88.88 & 11.12 \\
\hline Turkey & 71.43 & 28.57 & 66.67 & 33.33 & 71.43 & 28.57 \\
\hline United Arab Emirates & 0 & 100 & 100 & 0 & 78.95 & 21.05 \\
\hline United Kingdom & 72.97 & 27.03 & 74.34 & 25.66 & 79.22 & 20.78 \\
\hline United States & 93.88 & 6.12 & 74.90 & 25.10 & 80.82 & 19.18 \\
\hline
\end{tabular}

Table II - Women as editor-in-chief or directors, area and quartile of the journal and their relationship with the participation of women in other editorial positions.

\section{Women on the Editorial Committee Women on the Advisory Committee} Journals \% Median RIQ $\underset{\text { value }}{p}$ Journals \% Median RIQ $\begin{gathered}p \\ \text { value }\end{gathered}$

\section{Women as Editors-in-Chief/Directors}

$\begin{array}{llllllllllll}\text { No } & 96 / 154 & 62.33 & 1 & (0 \text { to } 3) & 0.000 & 119 / 154 & 93.4 & 4 & (1 \text { to } 10) & 0.000 \\ \text { Yes } & 26 / 35 & 74.28 & 3 & (0 \text { to } 6) & & 25 / 35 & 95.8 & 5 & (0 \text { to } 11)\end{array}$

$\mathrm{RIQ}=$ Interquartile range. 


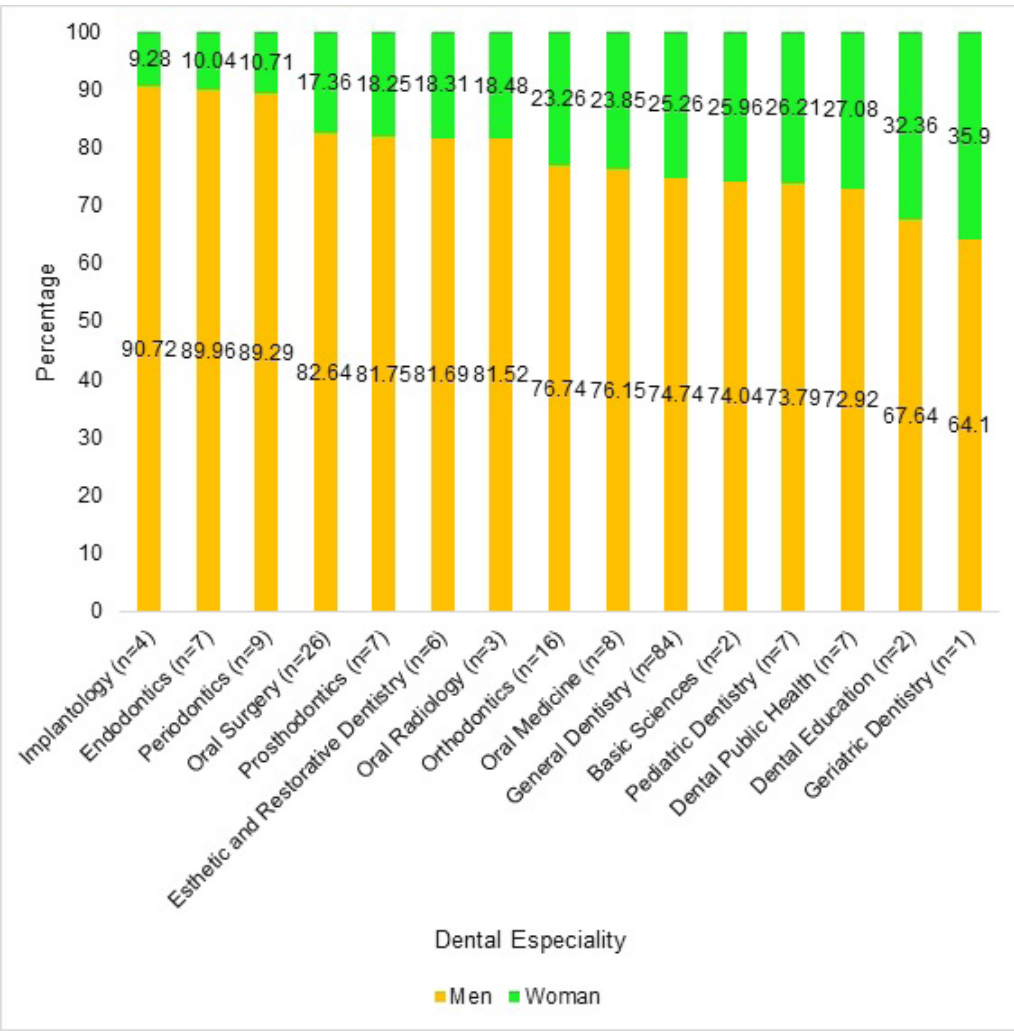

Figure 3 - Proportion of women on editorial committees of dental journals, by specialty.

\section{DISCUSSION}

Our findings show the low representation of women on the editorial boards of dental journals. Regarding editorial leadership, a supremacy of men in relation to women was evidenced $(168 / 39)$, being similar to that reported by Ioannidou and Rosania [9], who found that only 2 of the 69 dental journals included in the Journal Citation Reports had women as editor-inchief. Another study in Pakistani dental journals reported that only 10 (2.4\%) women served as editor-in-chief [10]. Similar results are evidenced in the other positions within Ioannidou and Rosania editorial committees [9], reported that only $16 \%$ of associate editors in dental journals. Likewise, in medical journals Lobl et al. [11], reported that only $36 \%$ and $22 \%$ of associate editor positions and members of the editorial board in dermatology journals were made up of women. Additionally, Pagel et al. [12], found that $13 \%$ of associate editors were women in the Journal of Cardiothoracic and Vascular Anesthesia.

There are challenges faced by women worldwide when seeking a balance between work and personal life, affecting their participation in research [13-15], which could lead to low productivity. Edmunds et al. [16] concluded that the lack of archetypes to follow, limited access to funding for research, discrimination, and gender bias were factors associated with the underrepresentation of women in research $[17,18]$. Low research productivity and underrepresentation on editorial boards are poorly reflected on women researchers' resumes, which can create additional barriers to seeking successful grants and promotions [19].

Regarding the quartile of the journal, it was observed that in journals with a better position (Q1-Q2) a greater female representation. This could be due to initiatives for the inclusion of women in science and research. For example, The Lancet journals announced in December 2017 the \#LancetWomen project, which aims to increase the presence of women in the editorial committees of its journals [20], and increase the proportion of reviewers from $25 \%$ to $35 \%$ by 2020 [21]. Likewise, the pertaining journals to the Elsevier collection now show the gender of the editors in support of gender equality.

The low representation of women in the editorial committees of dental journals is notorious in the analyzed countries, where the participation of men in the editorial committees 
represents more than double that of women. Comparing this finding with the gender gap index that analyses the division of resources and opportunities between men and women in 153 countries such as France, Chile, Taiwan, and Italy, they showed significant progress in reducing the gender gap. This situation is reflected in the present study, where these countries showed the highest participation of women in the editorial committees of their journals [2].

Our study highlights the underrepresentation of women in the editorial committees of the main dental journals in the 32 countries. Inclusion in an editorial committee fosters greater prestige that can influence future hiring, permanence, or job promotion [22]. The low representation of women in the positions of editor-in-chief and/or directors can negatively influence the proportion of women in other editorial positions [23]. It was only evidenced that Chile and the United Arab Emirates were the only countries where there was a supremacy of women as editors-in-chief or directors, contradictory to what was reported by the World Bank on countries with greater gender equality in 2020 [2], where countries such as Canada, Denmark, France and Sweden top this list. However, they showed a low representation of women in editorial leadership positions. This may affect the diversity of future editors-in-chief in the different countries, creating a feedback loop that maintains high male representation on editorial boards [24].

In certain areas such as geriatric dentistry, dental education, dental public health, and pediatric dentistry, the participation of women in editorial boards achieved better parity indicators compared to implantology, endodontics, periodontics, and oral surgery, being similar to that reported by Ioannidou and Rosania [9], where journals on dental public health, pediatric dentistry showed greater female representation in editorial committees, otherwise it was the areas of periodontics and oral surgery.

It was observed that the increase in the proportion of women in main positions, such as directors and editor-in-chief, was associated with a higher proportion of female editors, coinciding with that reported by Ioannidou and Rosania [9]. They found a significant association between the women in dental journal editorial leadership and women as editorial and advisory board members. ( $p=0.000)$. Likewise, Sarna et al. [7] reported an increase in women on the editorial board in medical journals when a woman assumed the leadership position $(\mathrm{p}<0.001)$.

The present research has some limitations due to considering only the dental journals included in the $S J R$, not including other scientific dental journals indexed to other databases. In addition, some journals could have an organizational structure with different roles within their editorial committee and categorized in this study and web pages that are outdated in editorial positions.

In conclusion, there is low participation of women in the editorial committees of dental journals globally. Female researchers have greater involvement in journals with a better quartile. It is favorable to encourage more and more the participation of women in the scientific community, in this particular case, within editorial committees.

\section{Acknowledgments}

None.

\section{Conflict of Interest}

The authors declare no conflict of interest.

\section{Funding} authors.

The present study was self-financed by the

\section{Regulatory Statement}

The data analyzed are publicly available and freely accessible, so prior approval by an institutional ethics committee is not considered necessary.

\section{REFERENCES}

1. Petrongolo B. The gender gap in employment and wages. Nat Hum Behav. 2019;3(4):316-8. http://dx.doi.org/10.1038/s41562019-0558-x. PMid:30971796.

2. Committed to Improving the State of the World. The Global gender gap report 2020. Geneva: World Economic Forum; 2019 [cited 2021 june 10]. Available from: https://wef.ch/2M3ZO1G

3. García-Calvente MM, Ruiz-Cantero MT, Del Río-Lozano M, Borrell C, López-Sancho MP. Gender inequalities in research in public health and epidemiology in Spain (2007-2014). Gac Sanit. 2015;29(6):404-11. PMid:26404162.

4. Albornoz M, Barrere R, Matas L, Osorio L, Sokil J. Gender gaps in Ibero-American scientific production. 2018 [cited 2021 june 
10]. Available from: https://www.clacso.org/wp-content/ uploads/2020/05/FOLEC-DIAGNOSTICO-INGLES.pdf

5. Leyva-Huerta ER, Gaitán-Cepeda LA. The importance of the scientific journals: a new age for the Revista Odontologica Mexicana. Rev Odontol Mex. 2019;23(1):6-8.

6. Algase DL. Editorial Advisory Boards: what are they and what do they do? Res Theory Nurs Pract. 2013;27(2):83-4. http://dx.doi. org/10.1891/1541-6577.27.2.83. PMid:24052997.

7. Sarna KV, Griffin T, Tarlov E, Gerber BS, Gabay MP, Suda KJ. Trends in gender composition on editorial boards in leading medicine, nursing, and pharmacy journals. J Am Pharm Assoc. 2020;60(4):565-70. http://dx.doi.org/10.1016/j. japh.2019.12.018. PMid:31953121.

8. Jalilianhasanpour R, Charkhchi P, Mirbolouk M, Yousem DM. Underrepresentation of women on radiology editorial boards. J Am Coll Radiol. 2019;16(1):115-20. http://dx.doi.org/10.1016/j. jacr.2018.08.017. PMid:30340997.

9. Ioannidou E, Rosania A. Under-representation of women on dental journal editorial boards. PLoS One. 2015;10(1):e0116630. http:// dx.doi.org/10.1371/journal.pone.0116630. PMid:25635691.

10. Bakht N, Arshad S, Zaidi SSN. Under-representation of women in the editorial boards of medical and dental journals of Pakistan. J Pak Med Assoc. 2017;67(5):722-4. PMid:28507359.

11. Lobl M, Grinnell M, Higgins S, Yost K, Grimes P, Wysong A. Representation of women as editors in dermatology journals: a comprehensive review. Int J Womens Dermatol. 2019;6(1):20-4. http://dx.doi.org/10.1016/j.ijwd.2019.09.002. PMid:32025556

12. Pagel PS, Freed JK, Lien CA. Gender composition and trends of journal of cardiothoracic and vascular anesthesia editorial board membership: a 33-year analysis, 1987-2019. J Cardiothorac Vasc Anesth. 2019;33(12):3229-34. http://dx.doi.org/10.1053/j. jvca.2019.07.139. PMid:31412981.

13. Nordblad A. Challenges for the leadership of oral health care in Finland. J Dent Educ. 2004;68(7, Suppl.):26-7. http://dx.doi.org/1 0.1002/j.0022-0337.2004.68.7_suppl.tb03812.x. PMid:15282248.

14. Nagda SJ. Harmonizing professional, personal, and social responsibilities: indian women dentists' perspectives. J Dent Educ. 2015;79(5, Suppl.):S23-6. http://dx.doi.org/10.1002/ j.0022-0337.2015.79.5suppl.tb05924.x. PMid:25941237.

15. Sembawa S, Sabbah W, Gallagher J. Professional aspirations and cultural expectations: a qualitative study of Saudi females in dentistry. JDR Clin Trans Res. 2018;3(2):150-60. http://dx.doi. org/10.1177/2380084418757696. PMid:30931769.

16. Edmunds LD, Ovseiko PV, Shepperd S, Greenhalgh T, Frith T, Roberts NW, et al. Why do women choose or reject careers in academic medicine? A narrative review of empirical evidence. Lancet. 2016;388(10062):2948-58. http://dx.doi.org/10.1016/ S0140-6736(15)01091-0. PMid:27105721.

17. Ceci SJ, Williams WM. Understanding current causes of women's underrepresentation in science. Proc Natl Acad Sci USA. 2011;108(8):3157-62. http://dx.doi.org/10.1073/ pnas.1014871108. PMid:21300892.

18. Chambers D, Preston L, Topakas A, De Saille S, Salway S, Booth $A$, et al. Review of diversity and inclusion literature and an evaluation of methodologies and metrics relating to health research. Sheffield: University of Sheffield; 2017 [cited 2021 june 10]. Available from: https://wellcome.org/sites/default/ files/review-of-diversity-and-inclusion-literature.pdf

19. Clark J, Horton R. What is The Lancet doing about gender and diversity? Lancet. 2019;393(10171):508-10. http://dx.doi. org/10.1016/S0140-6736(19)30289-2. PMid:30739674.

20. Bachelet VC. Advancing women in science, medicine and global health: on the \#LancetWomen special issue. Medwave. 2019;19(2):e7598. http://dx.doi.org/10.5867/ medwave.2019.02.7598. PMid:30897071.

21. Elsevier. Elseviers journals now displaying editors gender in support of diversity. Amsterdam; 2021 [cited 2021 june 10]. Available from: https://www.elsevier.com/about/pressreleases/corporate/elseviers-journals-now-displaying-editorsgender-in-support-of-diversity

22. Topaz CM, Sen S. Gender representation on journal editorial boards in the mathematical sciences. PLoS One. 2016;11(8):e0161357. http://dx.doi.org/10.1371/journal. pone.0161357. PMid:27536970.

23. Grinnell M, Higgins S, Yost K, Ochuba O, Lobl M, Grimes P, et al. The proportion of male and female editors in women's health journals: a critical analysis and review of the sex gap. Int $J$ Womens Dermatol. 2019;6(1):7-12. http://dx.doi.org/10.1016/j. ijwd.2019.11.005. PMid:32025554

24. Mauleón E, Hillán L, Moreno L, Gómez I, Bordons M. Assessing gender balance among journal authors and editorial board members. Scientometrics. 2013;95(1):87-114. http://dx.doi. org/10.1007/s11192-012-0824-4.

Christian Renzo Aquino Canchari

(Corresponding address)

Universidad Peruana Los Andes, Facultad de Medicina Humana, Sociedad Científica

de Estudiantes de Medicina Los Andes, Huancayo, Perú.

Email: christian.aquino.canchari@gmail.com

Date submitted: 2021 June 23

Accept submission: 2021 September 28 